\title{
Contribution of components of Green Supply Chain Procurement in Green Supply Chain Performance measurement-A Pilot Empirical Study of the Indian Automobile Manufacturing Sector
}

\author{
Mohd. Asif Gandhi ${ }^{1}$ \\ ${ }^{I}$ Department of Mechanical Engineering, Anjumain-I-Islam's Kalsekar Technical Campus, School of \\ Engineering and Technology, Mumbai University, India
}

\begin{abstract}
This paper is one of the several extensions of the research works done by [5]. Green Supply Chain Practices have been known to have an impact on Green Supply Chain Performance [5].This paper tests empirically through a pilot study of the Indian Automobile Manufacturing Sector, the contribution of the eleven variables constituting the construct Green Supply Chain Procurement in Green Supply Chain Performance measurement. Also the paper establishes the reliability of the questionnaire instrument developed previously for measuring the construct Green Supply Chain Procurement and also for measuring the eleven variables that constitute the construct Green Supply Chain Procurement. Further the paper establishes the correlation among these eleven variables. Finally this paper conducts Confirmatory Factor Analysis (CFA) to arrive at three factors (linear combination of eleven variables constituting the construct Green Supply Chain Procurement) to aid in measuring the construct Green Supply Chain Procurement. Finally the paper establishes the order of contribution of the eleven variables constituting the construct Green Supply Chain Procurement.
\end{abstract}

Keywords : Automobile, CFA, Green Supply Chain Performance, Green Supply Chain Practices, Green Supply Chain Procurement, Indian, Manufacturing Sector, Pilot Study.

\section{Introduction}

Green Supply Chain Procurement has been identified as one of the ten Green Supply Chain Performance measures which are impacted by five Green Supply Chain Practices [5]. Accordingly, this paper identifies the variables constituting the construct Green Supply Chain Procurement [5]. Green Supply Chain Procurement in turn is a sub-construct of the main construct Green Supply Chain Performance. Since Green Supply Chain Procurement has been identified as being constituted of eleven variables, it is of interest to know how these eleven variables fare in the pilot empirical study of the Indian automobile manufacturing sector by means of a questionnaire instrument [5]. It is also of interest to know the order of contribution of these eleven variables constituting the construct Green Supply Chain Procurement. The 50 automobile manufacturing plants that were surveyed during the pilot empirical study are among the ones listed in [2]. The survey methodology was used in line with the findings of [3].

\section{Research Questions}

The six research questions identified are as follows:

Research Question 1. To have a feel of the responses of the Indian Automobile Manufacturing Sector pertaining to the eleven variables constituting the construct Green Supply Chain Procurement.

Research Question 2. To know the reliability of the questionnaire instrument for measuring the construct Green Supply Chain Procurement.

Research Question 3. To know the reliability of the questionnaire instrument for measuring the eleven variables constituting the construct Green Supply Chain Procurement.

Research Question 4. How are the eleven variables constituting the construct Green Supply Chain Procurement correlated?

Research Question 5. How many factors are retained by the eleven variables constituting the construct Green Supply Chain Procurement?

Research Question 6. What is the order of contribution of the eleven variables constituting the construct Green Supply Chain Procurement?

\section{The Construct Green Supply Chain Procurement And Its Eleven Component Variables Used In The Study}

There are eleven variables that constitute the construct Green Supply Chain Procurement. They are depicted in the Table 1 in their abbreviated form. 
Table 1. The five variables constituting the construct Green Supply Chain Planning

\begin{tabular}{|c|c|c|c|c|c|c|c|c|c|c|c|}
\hline $\begin{array}{c}\text { The eleven } \\
\text { variables } \\
\text { constituting the } \\
\text { construct Green } \\
\begin{array}{c}\text { Supply Chain } \\
\text { Procurement }\end{array}\end{array}$ & GSCPROC1 & GSCPROC2 & GSCPROC3 & GSCPROC4 & GSCPROC5 & GSCPROC6 & GSCPROC7 & GSCPROC8 & GSCPROC9 & GSCPROC10 & GSCPROC11 \\
\hline
\end{tabular}

\section{The Descriptive Statistics Of The Scaled Data On Green Supply Chain Procurement}

A five point balanced Likert scale was used to scale the data from respondents on whom a questionnaire was administered. The respondents were employees of Indian automobile manufacturing firms and /or their plants as mentioned in [2]. The data collected revealed the following descriptive statistics of the eleven variables constituting the construct Green Supply Chain Procurement.

Table 2. Descriptive Statistics of the data scaled by the questionnaire on Green Supply Chain Procurement

\begin{tabular}{|c|c|c|c|c|c|c|}
\hline \multicolumn{7}{|c|}{ Simple Statistics } \\
\hline Variable & $\mathrm{N}$ & Mean & Std Dev & Sum & Minimum & Maximum \\
\hline GSCPROC1 & 50 & 4.04000 & 1.00934 & 202.00000 & 2.00000 & 5.00000 \\
\hline GSCPROC2 & 50 & 3.98000 & 1.03982 & 199.00000 & 1.00000 & 5.00000 \\
\hline GSCPROC3 & 50 & 4.58000 & 0.70247 & 229.00000 & 2.00000 & 5.00000 \\
\hline GSCPROC4 & 50 & 4.36000 & 1.15635 & 218.00000 & 1.00000 & 5.00000 \\
\hline GSCPROC5 & 50 & 4.34000 & 1.17125 & 217.00000 & 1.00000 & 5.00000 \\
\hline GSCPROC6 & 50 & 4.44000 & 0.50143 & 222.00000 & 4.00000 & 5.00000 \\
\hline GSCPROC7 & 50 & 3.68000 & 1.16829 & 184.00000 & 1.00000 & 5.00000 \\
\hline GSCPROC8 & 50 & 4.02000 & 1.05926 & 201.00000 & 1.00000 & 5.00000 \\
\hline GSCPROC9 & 50 & 3.98000 & 1.03982 & 199.00000 & 1.00000 & 5.00000 \\
\hline GSCPROC10 & 50 & 3.68000 & 1.16829 & 184.00000 & 1.00000 & 5.00000 \\
\hline
\end{tabular}

\section{The Reliability Of The Instrument For The Variables And Construct Used}

The reliability of the questionnaire instrument developed by [5] for the construct Green Supply Chain Procurement is shown in the Table 3 as 0.954046 which is considered to be excellent [4].

Table 3. Reliability by Cronbach's Coefficient Alpha for the construct Green Supply Chain Procurement

\begin{tabular}{|c|c|}
\hline \multicolumn{2}{|c|}{ Cronbach Coefficient Alpha } \\
\hline Variables & Alpha \\
\hline Raw & 0.960878 \\
\hline Standardized & 0.954046 \\
\hline
\end{tabular}

The reliability of the questionnaire for the eleven variables that constitute the construct Green Supply Chain Procurement is shown in the Table 4 . All the eleven variables in Table 4 have a reliability greater than 0.9 which is considered as excellent [4].

Table 4. Reliability of the individual eleven variables constituting the construct Green Supply Chain Procurement

\begin{tabular}{|c|c|c|c|c|}
\hline \multicolumn{5}{|c|}{ Cronbach Coefficient Alpha with Deleted Variable } \\
\hline \multirow{2}{*}{$\begin{array}{l}\text { Deleted } \\
\text { Variable }\end{array}$} & \multicolumn{2}{|c|}{ Raw Variables } & \multicolumn{2}{|c|}{ Standardized Variables } \\
\hline & $\begin{array}{c}\text { Correlation } \\
\text { with Total }\end{array}$ & Alpha & $\begin{array}{c}\text { Correlation } \\
\text { with Total }\end{array}$ & Alpha \\
\hline GSCPROC1 & 0.973225 & 0.951758 & 0.958534 & 0.943507 \\
\hline GSCPROC2 & 0.979401 & 0.951388 & 0.968435 & 0.943142 \\
\hline GSCPROC3 & 0.700877 & 0.961093 & 0.711901 & 0.952361 \\
\hline GSCPROC4 & 0.887962 & 0.954624 & 0.868610 & 0.946788 \\
\hline GSCPROC5 & 0.881637 & 0.954910 & 0.865232 & 0.946910 \\
\hline GSCPROC6 & 0.132287 & 0.971380 & 0.138479 & 0.971233 \\
\hline GSCPROC7 & 0.855295 & 0.955919 & 0.852291 & 0.947377 \\
\hline GSCPROC8 & 0.983641 & 0.951151 & 0.967221 & 0.943186 \\
\hline GSCPROC9 & 0.979401 & 0.951388 & 0.968435 & 0.943142 \\
\hline GSCPROC10 & 0.855295 & 0.955919 & 0.852291 & 0.947377 \\
\hline GSCPROC11 & 0.570357 & 0.964204 & 0.587822 & 0.956644 \\
\hline
\end{tabular}

\section{The Pearson's Correlation Coefficient Among The Variables Used In The Study}

The Pearson's Correlation coefficient between different pairs of variables that constitute the construct Green Supply Chain Procurement is shown in the Table 5. Since all the values of correlation coefficient are above 0.9, it indicates that all the eleven variables that make up the construct Green Supply Chain Procurement are oriented towards the goal of Green Supply Chain Procurement in a unidirectional manner. 
Table 5. Pearson's Correlation coefficient

\begin{tabular}{|c|c|c|c|c|c|c|c|c|c|c|c|}
\hline \multicolumn{12}{|c|}{$\begin{array}{l}\text { Pearson Correlation Coefficients, } \mathrm{N}=50 \\
\text { Prob }>|\mathrm{r}| \text { under } \mathrm{H} 0: \text { Rho }=0\end{array}$} \\
\hline & $\begin{array}{l}\text { GSCPR } \\
\text { OC1 }\end{array}$ & $\begin{array}{l}\text { GSCPR } \\
\text { OC2 }\end{array}$ & $\begin{array}{l}\text { GSCPR } \\
\text { OC } 3\end{array}$ & $\begin{array}{l}\text { GSCPR } \\
\text { OC4 }\end{array}$ & $\begin{array}{l}\text { GSCPR } \\
\text { OC5 }\end{array}$ & $\begin{array}{l}\text { GSCPR } \\
\text { OC6 }\end{array}$ & $\begin{array}{l}\text { GSCPR } \\
\text { OC7 }\end{array}$ & $\begin{array}{l}\text { GSCPR } \\
\text { OC8 }\end{array}$ & $\begin{array}{l}\text { GSCPR } \\
\text { OC9 }\end{array}$ & $\begin{array}{c}\text { GSCPR } \\
\text { OC } 10\end{array}$ & $\begin{array}{c}\text { GSCPR } \\
\text { OC11 }\end{array}$ \\
\hline $\begin{array}{l}\text { GSCPR } \\
\text { OC1 }\end{array}$ & 1.00000 & $\begin{array}{l}0.97303 \\
<.0001\end{array}$ & $\begin{array}{c}0.65740 \\
<.0001\end{array}$ & $\begin{array}{c}0.89665 \\
<.0001\end{array}$ & $\begin{array}{c}0.88593 \\
<.0001\end{array}$ & $\begin{array}{c}0.12581 \\
0.3840\end{array}$ & $\begin{array}{c}0.91103 \\
<.0001\end{array}$ & $\begin{array}{c}0.99181 \\
<.0001\end{array}$ & $\begin{array}{c}0.97303 \\
<.0001\end{array}$ & $\begin{array}{c}0.91103 \\
<.0001 \\
\end{array}$ & $\begin{array}{c}0.47876 \\
0.0004\end{array}$ \\
\hline $\begin{array}{l}\text { GSCPR } \\
\text { OC2 }\end{array}$ & $\begin{array}{c}0.97303 \\
<.0001 \\
\end{array}$ & 1.00000 & $\begin{array}{c}0.68675 \\
<.0001 \\
\end{array}$ & $\begin{array}{c}0.90568 \\
<.0001 \\
\end{array}$ & $\begin{array}{c}0.89382 \\
<.0001 \\
\end{array}$ & $\begin{array}{c}0.13465 \\
0.3512\end{array}$ & $\begin{array}{c}0.88500 \\
<.0001 \\
\end{array}$ & $\begin{array}{c}0.98238 \\
<.0001 \\
\end{array}$ & $\begin{array}{c}1.00000 \\
<.0001 \\
\end{array}$ & $\begin{array}{c}0.88500 \\
<.0001 \\
\end{array}$ & $\begin{array}{c}0.53022 \\
<.0001 \\
\end{array}$ \\
\hline $\begin{array}{c}\text { GSCPR } \\
\text { OC3 }\end{array}$ & $\begin{array}{c}0.65740 \\
<.0001 \\
\end{array}$ & $\begin{array}{c}0.68675 \\
<.0001 \\
\end{array}$ & 1.00000 & $\begin{array}{c}0.76778 \\
<.0001 \\
\end{array}$ & $\begin{array}{c}0.77240 \\
<.0001 \\
\end{array}$ & $\begin{array}{c}0.18772 \\
0.1917 \\
\end{array}$ & $\begin{array}{c}0.40484 \\
0.0035\end{array}$ & $\begin{array}{c}0.64233 \\
<.0001 \\
\end{array}$ & $\begin{array}{c}0.68675 \\
<.0001 \\
\end{array}$ & $\begin{array}{c}0.40484 \\
0.0035 \\
\end{array}$ & $\begin{array}{c}0.74501 \\
<.0001 \\
\end{array}$ \\
\hline $\begin{array}{c}\text { GSCPR } \\
\text { OC4 }\end{array}$ & $\begin{array}{c}0.89665 \\
<.0001\end{array}$ & $\begin{array}{c}0.90568 \\
<.0001\end{array}$ & $\begin{array}{c}0.76778 \\
<.0001\end{array}$ & 1.00000 & $\begin{array}{c}0.99270 \\
<.0001\end{array}$ & $\begin{array}{c}- \\
0.17317 \\
0.2291 \\
\end{array}$ & $\begin{array}{c}0.66106 \\
<.0001\end{array}$ & $\begin{array}{c}0.91038 \\
<.0001\end{array}$ & $\begin{array}{c}0.90568 \\
<.0001\end{array}$ & $\begin{array}{c}0.66106 \\
<.0001\end{array}$ & $\begin{array}{c}0.61475 \\
<.0001\end{array}$ \\
\hline $\begin{array}{c}\text { GSCPR } \\
\text { OC5 }\end{array}$ & $\begin{array}{c}0.88593 \\
<.0001\end{array}$ & $\begin{array}{c}0.89382 \\
<.0001\end{array}$ & $\begin{array}{c}0.77240 \\
<.0001\end{array}$ & $\begin{array}{c}0.99270 \\
<.0001\end{array}$ & 1.00000 & $\begin{array}{c}- \\
0.15568 \\
0.2803\end{array}$ & $\begin{array}{c}0.64788 \\
<.0001\end{array}$ & $\begin{array}{c}0.89912 \\
<.0001\end{array}$ & $\begin{array}{c}0.89382 \\
<.0001\end{array}$ & $\begin{array}{c}0.64788 \\
<.0001\end{array}$ & $\begin{array}{c}0.63958 \\
<.0001\end{array}$ \\
\hline $\begin{array}{c}\text { GSCPR } \\
\text { OC6 }\end{array}$ & $\begin{array}{c}0.12581 \\
0.3840\end{array}$ & $\begin{array}{c}0.13465 \\
0.3512\end{array}$ & $\begin{array}{c}0.18772 \\
0.1917\end{array}$ & $\begin{array}{c}- \\
0.17317 \\
0.2291\end{array}$ & $\begin{array}{c}- \\
0.15568 \\
0.2803\end{array}$ & 1.00000 & $\begin{array}{c}0.34977 \\
0.0128\end{array}$ & $\begin{array}{c}0.09836 \\
0.4968\end{array}$ & $\begin{array}{c}0.13465 \\
0.3512\end{array}$ & $\begin{array}{c}0.34977 \\
0.0128\end{array}$ & $\begin{array}{c}0.18233 \\
0.2051\end{array}$ \\
\hline $\begin{array}{c}\text { GSCPR } \\
\text { OC7 }\end{array}$ & $\begin{array}{c}0.91103 \\
<.0001\end{array}$ & $\begin{array}{c}0.88500 \\
<.0001\end{array}$ & $\begin{array}{c}0.40484 \\
0.0035\end{array}$ & $\begin{array}{c}0.66106 \\
<.0001\end{array}$ & $\begin{array}{c}0.64788 \\
<.0001\end{array}$ & $\begin{array}{c}0.34977 \\
0.0128\end{array}$ & 1.00000 & $\begin{array}{c}0.91229 \\
<.0001\end{array}$ & $\begin{array}{c}0.88500 \\
<.0001\end{array}$ & $\begin{array}{c}1.00000 \\
<.0001\end{array}$ & $\begin{array}{c}0.36412 \\
0.0093\end{array}$ \\
\hline $\begin{array}{c}\text { GSCPR } \\
\text { OC8 }\end{array}$ & $\begin{array}{c}0.99181 \\
<.0001 \\
\end{array}$ & $\begin{array}{c}0.98238 \\
<.0001 \\
\end{array}$ & $\begin{array}{c}0.64233 \\
<.0001 \\
\end{array}$ & $\begin{array}{c}0.91038 \\
<.0001 \\
\end{array}$ & $\begin{array}{c}0.89912 \\
<.0001 \\
\end{array}$ & $\begin{array}{c}0.09836 \\
0.4968\end{array}$ & $\begin{array}{c}0.91229 \\
<.0001 \\
\end{array}$ & 1.00000 & $\begin{array}{c}0.98238 \\
<.0001 \\
\end{array}$ & $\begin{array}{c}0.91229 \\
<.0001 \\
\end{array}$ & $\begin{array}{c}0.53634 \\
<.0001 \\
\end{array}$ \\
\hline $\begin{array}{c}\text { GSCPR } \\
\text { OC9 } \\
\end{array}$ & $\begin{array}{c}0.97303 \\
<.0001 \\
\end{array}$ & $\begin{array}{c}1.00000 \\
<.0001 \\
\end{array}$ & $\begin{array}{c}0.68675 \\
<.0001 \\
\end{array}$ & $\begin{array}{c}0.90568 \\
<.0001 \\
\end{array}$ & $\begin{array}{c}0.89382 \\
<.0001 \\
\end{array}$ & $\begin{array}{c}0.13465 \\
0.3512 \\
\end{array}$ & $\begin{array}{c}0.88500 \\
<.0001 \\
\end{array}$ & $\begin{array}{c}0.98238 \\
<.0001 \\
\end{array}$ & 1.00000 & $\begin{array}{c}0.88500 \\
<.0001 \\
\end{array}$ & $\begin{array}{c}0.53022 \\
<.0001 \\
\end{array}$ \\
\hline $\begin{array}{c}\text { GSCPR } \\
\text { OC10 }\end{array}$ & $\begin{array}{c}0.91103 \\
<.0001\end{array}$ & $\begin{array}{c}0.88500 \\
<.0001\end{array}$ & $\begin{array}{c}0.40484 \\
0.0035\end{array}$ & $\begin{array}{c}0.66106 \\
<.0001\end{array}$ & $\begin{array}{c}0.64788 \\
<.0001\end{array}$ & $\begin{array}{c}0.34977 \\
0.0128\end{array}$ & $\begin{array}{c}1.00000 \\
<.0001\end{array}$ & $\begin{array}{c}0.91229 \\
<.0001\end{array}$ & $\begin{array}{c}0.88500 \\
<.0001\end{array}$ & 1.00000 & $\begin{array}{c}0.36412 \\
0.0093\end{array}$ \\
\hline $\begin{array}{c}\text { GSCPR } \\
\text { OC11 }\end{array}$ & $\begin{array}{c}0.47876 \\
0.0004\end{array}$ & $\begin{array}{c}0.53022 \\
<.0001\end{array}$ & $\begin{array}{c}0.74501 \\
<.0001\end{array}$ & $\begin{array}{c}0.61475 \\
<.0001\end{array}$ & $\begin{array}{c}0.63958 \\
<.0001\end{array}$ & $\begin{array}{c}0.18233 \\
0.2051\end{array}$ & $\begin{array}{c}0.36412 \\
0.0093\end{array}$ & $\begin{array}{c}0.53634 \\
<.0001\end{array}$ & $\begin{array}{c}0.53022 \\
<.0001\end{array}$ & $\begin{array}{c}0.36412 \\
0.0093\end{array}$ & 1.00000 \\
\hline
\end{tabular}

\section{Factor Analysis}

Using statistical analysis software called SAS 9.2, Confirmatory Factor Analysis (CFA) was conducted on the construct Green Supply Chain Procurement which consists of eleven variables. Principal Component's method was used as the initial factor method. Accordingly the Eigenvalues were obtained as shown in the Table 6.

Table 6. Eigen values obtained by using Principal Components Method as the initial factor method.

\begin{tabular}{|c|c|c|c|c|}
\hline \multicolumn{5}{|c|}{ Eigenvalues of the Correlation Matrix: Total $=11$ Average $=1$} \\
\hline & Eigenvalue & Difference & Proportion & Cumulative \\
\hline 1 & 8.08467938 & 6.65352185 & 0.7350 & 0.7350 \\
\hline 2 & 1.43115753 & 0.34056061 & 0.1301 & 0.8651 \\
\hline 3 & 1.09059692 & 0.79602590 & 0.0991 & 0.9642 \\
\hline 4 & 0.29457102 & 0.24346818 & 0.0268 & 0.9910 \\
\hline 5 & 0.05110285 & 0.00856355 & 0.0046 & 0.9956 \\
\hline 6 & 0.04253929 & 0.03718629 & 0.0039 & 0.9995 \\
\hline 7 & 0.00535301 & 0.00535301 & 0.0005 & 1.0000 \\
\hline 8 & 0.00000000 & 0.00000000 & 0.0000 & 1.0000 \\
\hline 9 & 0.00000000 & 0.00000000 & 0.0000 & 1.0000 \\
\hline 10 & 0.00000000 & 0.00000000 & 0.0000 & 1.0000 \\
\hline 11 & 0.00000000 & & 0.0000 & 1.0000 \\
\hline
\end{tabular}

An Eigen value indicate the relative importance of each factor in accounting for the particular set of variables being analysed. From Table 6 it is clear that the first factor can explain 8.08467938 variables. The second factor can explain 1.43115753 variables. The third factor can explain 1.09059692 variables. Hence all the three factors are desirable factors. No other factor in the Table 6 can explain at least one variable. Hence the first factor, the second factor and the third factor will be retained by MINEIGEN criterion as the only factors as shown by the factor pattern of Table 7 . The variance explained by the three factors is $8.0846794,1.4311575$ and 1.0905969 . 
Table7. Factor pattern obtained for the single factor retained by MINEIGEN criterion

\begin{tabular}{|c|c|c|c|}
\hline \multicolumn{4}{|c|}{ Factor Pattern } \\
\hline & Factor1 & Factor2 & Factor3 \\
\hline GSC_Pro1 & 0.98049 & 0.07321 & -0.14114 \\
\hline GSC_Pro2 & 0.98576 & 0.04131 & -0.08640 \\
\hline GSC_Pro3 & 0.74216 & -0.31111 & 0.50163 \\
\hline GSC_Pro4 & 0.92658 & -0.35668 & -0.07472 \\
\hline GSC_Pro5 & 0.92081 & -0.36267 & -0.04024 \\
\hline GSC_Pro6 & 0.14792 & 0.77990 & 0.58777 \\
\hline GSC_Pro7 & 0.87573 & 0.43373 & -0.16849 \\
\hline GSC_Pro8 & 0.98868 & 0.04450 & -0.13370 \\
\hline GSC_Pro9 & 0.98576 & 0.04131 & -0.08640 \\
\hline GSC_Pro10 & 0.87573 & 0.43373 & -0.16849 \\
\hline GSC_Pro11 & 0.62405 & -0.28348 & 0.61383 \\
\hline
\end{tabular}

The final communality estimates for the eleven variables constituting the construct Green Supply Chain Procurement are shown in Table 8.

Table 8. The final communality estimates for Pollution Prevention

\begin{tabular}{|l|l|l|l|l|l|l|l|l|r|r|}
\hline \multicolumn{10}{|c|}{ Final Communality Estimates: Total = 10.606434 } \\
\hline GSCPR & GSCPR & GSCPR & GSCPR & GSCPR & GSCPR & GSCPR & GSCPR & GSCPR & \multicolumn{1}{l|}{ GSCPRO } & GSCPRO \\
OC1 & OC2 & OC3 & OC4 & OC5 & OC6 & OC7 & OC8 & OC9 & C10 & C11 \\
\hline 0.986632 & 0.980898 & 0.899224 & 0.991358 & 0.981047 & 0.975605 & 0.983410 & 0.997352 & 0.980898 & 0.983410 & 0.846594 \\
60 & 27 & 63 & 58 & 66 & 33 & 81 & 17 & 27 & 81 & 71 \\
\hline
\end{tabular}

Communality estimates are indicative of how much of each variable is accounted for by the underlying factors taken together. A high value of communality means that not much of the variable is left over after whatever the factors represent is taken into consideration. In short the communality estimates are indicative of the relative contribution of each of the variables in the construct. Accordingly Figure 1shows in the descending order, the relative contribution of each of the eleven variables of the construct Green Supply Chain Procurement as follows: GSCPROC8, GSCPROC4, GSCPROC1, GSCPROC7, GSCPROC10, GSCPROC5, GSCPROC2, GSCPROC9, GSCPROC6, GSCPROC3, GSCPROC11.

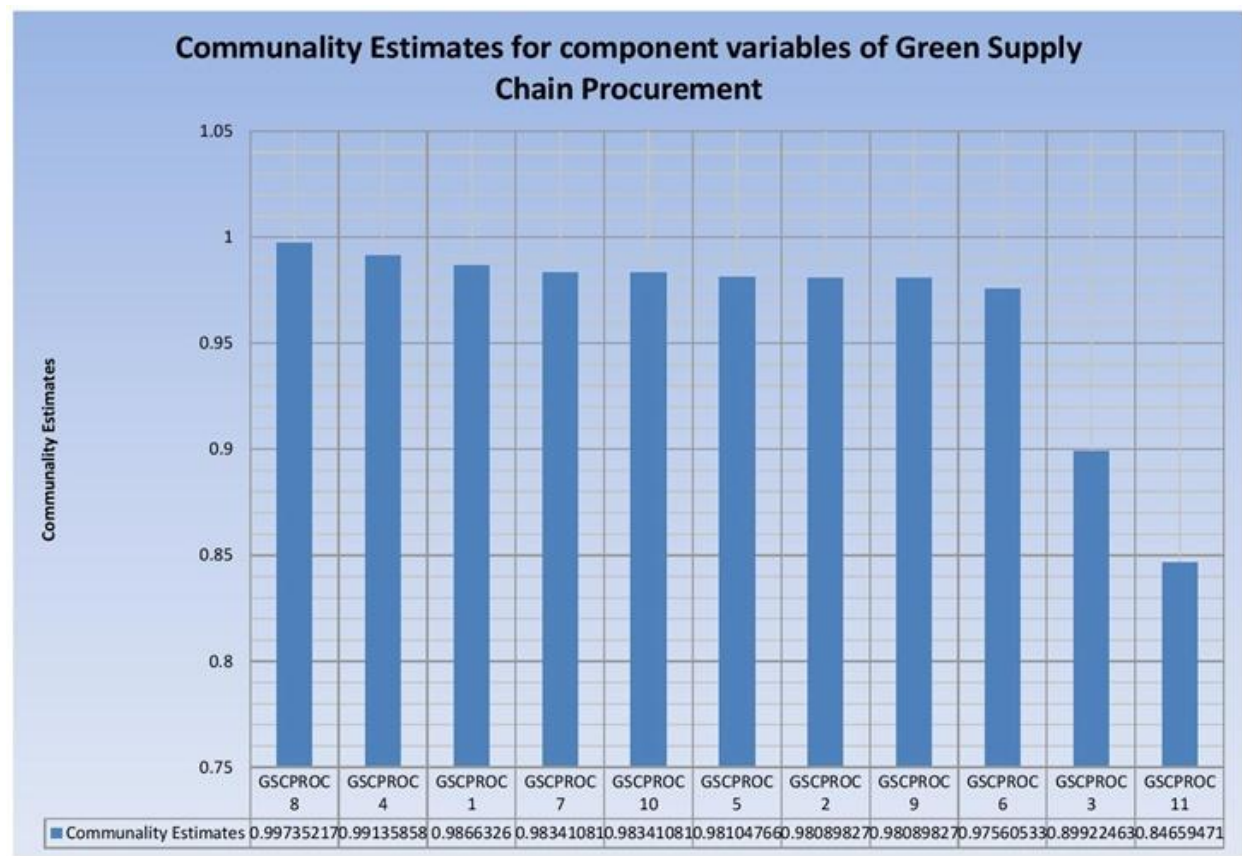

Figure 1. Contribution of the eleven components of Green Supply Chain Procurement in descending order.

\section{Conclusion}

The aim of this paper was to study the contribution of the eleven variables constituting the construct Green Supply Chain Procurement as a component measure of Green Supply Chain Performance. It was found that all the eleven variables in the study were strongly correlated with each of the other variables meaning that all the eleven variables involved are strongly oriented towards Green Supply Chain Procurement. The reliability of the construct Green Supply Chain Procurement was 0.954046 which is considered excellent. Also the 
reliability of the eleven variables constituting the construct Green Supply Chain Procurement was above 0.9 which means that the questionnaire is reliable to measure each of the variables and also the construct Green Supply Chain Procurement as a whole. Also the results of Confirmatory Factor Analysis reveal that three factor accounting for 8.08467938 variables, 1.43115753 variables and 4.2237678 variables and 1.09059692 variables are retained.

\section{Acknowledgements}

I express my heartfelt thanks to Dr. Abdul Razak Honnutagi for permitting me to go ahead with my research work from NITIE, Mumbai though our institute was at its formative stage. Also I acknowledge the patience and support of my wife Yasmin Mohd. Asif Gandhi for bearing with me during my long research hours for years. I express my heartfelt thanks to my parents Mr. Indravadan Chimanlal Gandhi and Mrs. Sarmista Indravadan Gandhi for encouraging me and motivating me to complete my research work. I dedicate all my success to them. Special thanks to my guide Dr. Sanjay Sharma from NITIE, Mumbai.

\section{References}

[1] Emmett, S. and Sood, V., Green Supply Chains - An Action Manifesto. John Wiles \& Sons, 2010, 59-91.

[2] Gandhi, M.A., A Review of the Indian Automobile Manufacturing Sector, IOSR Journal of Business and Management, 19(3), Ver II, 2017, 9-15.

[3] Gandhi, M.A. and Sharma, S., A Review of Research Methodologies Linking Green Supply Chain Practices and Green Supply Chain Performance, International Journal of Supply Chain Management, 3(4), 2014

[4] George, D., and Mallery, M. Using SPSS for Windows step by step: a simple guide and reference. 2003.

[5] Sharma, S., and Gandhi, M.A., Exploring correlations in components of green supply chain practices and green supply chain performance, Competitiveness Review, 26(3), 2016, 332-368. 